\title{
THE TEMPLE IN THE APOCALYPSE OF WEEKS AND IN HEBREWS
}

\author{
Philip Church
}

\begin{abstract}
Summary
Several Second Temple texts make no explicit mention of the temple, but it cannot be assumed that this silence indicates a lack of interest. While the Apocalypse of Weeks reveres Solomon's temple and describes it in ways that indicate that it anticipates the eschatological temple, the Second Temple is ignored, implying a strong polemic against it. Hebrews makes no explicit mention of the Second Temple, but several texts reflect a critique of temple, priesthood, and sacrificial system. Hebrews claims that the temple and its associated rituals were a symbolic foreshadowing of the eschatological dwelling of God with his people in the last days, now come with the exaltation of Christ. Since the reality has now come, the readers can no longer be occupied with the symbols.
\end{abstract}

\section{Introduction}

Hebrews is one of several texts from the Second Temple period that nowhere explicitly mentions the temple. Other texts from which the temple is absent include the Apocalypse of Weeks and Jubilees, both from the Second Century BC, and 4 Ezra and 2 Baruch from around the end of the First Century AD, both of which deal with the destruction of the Second Temple as though it was Solomon's temple. But silence about the temple cannot be taken as lack of interest in it as 2 Baruch and 4 Ezra illustrate. Sometimes where the temple is not explicitly mentioned, it is implied, and indeed the readers are supposed to infer that the author is making some point, usually negative, about it. I will illustrate this from the Apocalypse of Weeks and then argue that, while Hebrews is silent about the temple, it critiques temple, 
priesthood, and sacrifice. This essay advances the arguments about the significance of the unmentioned temple in Hebrews previously put forward by Peter Walker and Steve Motyer. ${ }^{1}$

\section{The Apocalypse of Weeks}

The Apocalypse of Weeks (ApW) analyses the history of the world into ten weeks, each of seven generations. ${ }^{2}$ It is embedded in the Epistle of Enoch (1 Enoch 91-105), ${ }^{3}$ the place it also occupies in Aramaic Enoch (4QEn $\left.{ }^{\mathrm{g}}, 4 \mathrm{Q} 212\right) .{ }^{4}$ In 1 Enoch the weeks are disordered, with weeks one to seven in 93:1-10, the end of week seven in 91:11, and weeks eight to ten in 91:12-17. In Aramaic Enoch, the Vorlagen of 1 En. 93:10 and 91:11 occupy consecutive lines, indicating that the weeks originally appeared in numerical order. It is debated whether this transposition was accidental or deliberate, but on balance it seems to have been deliberate, with the eschatological resolution in weeks eight to ten now setting the context in which the perversity of the present generation is to be understood. ${ }^{5}$

1 Peter W. L. Walker, 'Jerusalem in Hebrews 13:9-14 and the Dating of the Epistle', TynBul 45 (1994): 39-71; Jesus and the Holy City: New Testament Perspectives on Jerusalem (Grand Rapids, MI: Eerdmans, 1996): 203-210; 'A Place for Hebrews? Contexts for a First-Century Sermon' in The New Testament in Its First Century Setting: Essays on Context and Background in Honour of B. W. Winter on His 65th Birthday, ed. P. J. Williams et al. (Grand Rapids, MI/Cambridge: Eerdmans, 2004): 231-49; Steve Motyer, 'The Temple in Hebrews: Is It There?' in Heaven on Earth: The Temple in Biblical Theology, ed. T. Desmond Alexander and Simon Gathercole (Carlisle: Paternoster, 2004): 177-89. Scott D. Mackie, Eschatology and Exhortation in the Epistle to the Hebrews (WUNT 2, 223; Tübingen: Mohr (Siebeck), 2007): 84-85 concurs with the arguments put forward by Walker and Motyer.

2 Similar divisions of history appear in Dan. 9:20-27; Sib. Or. 1, 2 and 4; 11QMelch, 4Q Ages of Creation.

3 I need not enter the debate as to whether it was an earlier text embedded here, or whether it was an integral part of the Epistle of Enoch. See the discussion in Michael A. Knibb, 'The Apocalypse of Weeks and the Epistle of Enoch' in Enoch and Qumran Origins: New Light on a Forgotten Connection, ed. Gabriele Boccaccini et al. (Grand Rapids, MI: Eerdmans, 2005): 213-19.

$44 \mathrm{QEn}^{\mathrm{g}}$ is the earliest witness to $\mathrm{ApW}$, although it is severely damaged, with weeks three to six missing, and weeks two and seven fragmented. It is usually dated to around 50 BC, see J. T. Milik, The Books of Enoch: Aramaic Fragments of Qumrân Cave 4 (Oxford: Clarendon, 1976): 246. There is no extant Greek text of ApW, and the complete text is only preserved in Ethiopic. Unless otherwise noted, I quote from George W. E. Nickelsburg and James C. VanderKam, 1 Enoch: A New Translation Based on the Hermeneia Commentary (Minneapolis, MN: Fortress, 2004): 140-43.

5 I discuss this 'perversity' below. James C. VanderKam, 'Studies in the Apocalypse of Weeks (1 Enoch 93:1-10, 91:11-17)', CBQ 46 (1984): 511-23, esp. 518, and Daniel 
Only significant events are recounted, often in code, and generally at the conclusion of each week. The text has an ethical and religious substructure, with most weeks containing some critique of the wickedness of the people living at the time, and a reference to God's judgement for their wickedness. Significant events include the birth of Enoch (week one), Noah and the flood (week two), the election of Abraham (week three), law and tabernacle (week four), Solomon's temple (week five), the destruction of the temple followed by the exile (week six), and a perverse generation and a righteous remnant (week seven). After this the details are vague, with the eschaton anticipated. Most scholars agree that the author belongs to the seventh week, which probably ends somewhere around 175-170 BC, just prior to the Maccabean revolt, which is not mentioned. The composition is usually dated around this time. ${ }^{6}$

Scholars have noted a concentric structure to $\mathrm{ApW},{ }^{7}$ which begins and ends with enduring righteousness (93:3; 91:17). Deceit and violence arise in the second week (93:4), and vanish in the ninth (91:14). The appearance of Abraham and the plant of righteous

C. Olson, 'Recovering the Original Sequence of 1 Enoch 91-93', JSP 6 (1993): 69-91 are among the scholars who propose an accidental reordering of the weeks, while Michael A. Knibb, 'The Book of Enoch or Books of Enoch? The Textual Evidence for 1 Enoch' in The Early Enoch Literature, ed. Gabriele Boccaccini and John J. Collins (Leiden/Boston: Brill, 2007): 21-40, esp. 22, and George W. E. Nickelsburg, 1 Enoch 1: A Commentary on the Book of 1 Enoch, Chapters 1-36; 81-108 (Hermeneia; Minneapolis, MN: Fortress, 2001): 414-15 are representative of those who argue that it was deliberate.

6 VanderKam, 'Studies'; Nickelsburg, 1 Enoch 1, 440-41; Daniel C. Olson, Enoch: A New Translation: The Ethiopic Book of Enoch, or 1 Enoch. Translated with Annotations and Cross-References in Consultation with Archbishop Melkesedek Workeneh (North Richland Hills, TX: Bibal, 2004): 16; Loren T. Stuckenbruck, 1 Enoch 91-108 (CEJL; Berlin/New York, NY: Walter de Gruyter, 2007): 61-62. Ferdinand Dexinger, Henochs Zehnwochenapokalypse und offene Probleme der Apokalyptikforschung (StPB; Leiden: Brill, 1977): 139, detects a reference to the Maccabean revolt in the 'sword' that appears in the eighth week, and assigns a date after that revolt. Florentino García Martínez, 'Contributions of the Aramaic Enoch Fragments to Our Understanding of the Books of Enoch' in Qumran and Apocalyptic: Studies on the Aramaic Texts from Qumran, ed. F. García Martínez, and A. S. van der Woude (STDJ 9; Leiden: Brill, 1992): 86 argues that the 'sword' is more likely to be a reference to the eschatological battle, as in the related Animal Apocalypse (see 1 En. 90:19).

7 VanderKam, 'Studies', 518-21; Gabriele Boccaccini, Beyond the Essene Hypothesis: The Parting of the Ways between Qumran and Enochic Judaism (Grand Rapids, MI/Cambridge: Eerdmans, 1998): 107-109. Matthias Henze, 'The Apocalypse of Weeks and the Architecture of the End Time' in Enoch and Qumran Origins: New Light on a Forgotten Connection, ed. Gabriele Boccaccini et al. (Grand Rapids, MI: Eerdmans, 2005): 207-209 shows that the concentric structure is not completely tidy. 
judgement (Israel) from whom the plant of righteousness will go forth forever in the third week (93:5) have their counterpart in the building of the eschatological temple for all the generations in the eighth week (91:13). The giving of the law in the fourth week (93:6) contrasts with the perverse deeds of the perverse generation in the seventh (91:9). This leaves the two central weeks, five and six, in which Solomon's temple is constructed (fifth week, 93:7) and destroyed (sixth week, 93:8), followed by the exile.

The sixth week is perhaps the most significant. Here the entire race of the chosen root which will go forth forever (third week) is exiled, the law for all generations (fourth week) is nullified when everyone strays from wisdom, and the temple which was built to last forever (fifth week) is burned with fire. The third to the fifth weeks give the impression of permanence, but all comes crashing down in the sixth. In the seventh to the tenth weeks this is resolved with the election of the chosen remnant, the building of an eschatological temple, and the revelation of the righteous law to the whole earth.

The stark contrast between the description of Solomon's magnificent temple in the fifth week, as the temple of the glorious kingdom built to last forever, ${ }^{8}$ and its destruction in the sixth week when the people stray from wisdom, gives it considerable prominence. ${ }^{9}$ Moreover, the similarities between this description and that of the eschatological temple in the eighth week indicate that Solomon's temple was seen as the pinnacle of salvation history, destroyed because of the wickedness of the people. The eschatological temple picks up key features of Solomon's temple, indicating that Solomon's temple foreshadowed the eschatological temple. ${ }^{10}$

8 As Nickelsburg and VanderKam, 1 Enoch, 141, footnote h, note, Ethiopic beta has the sense 'house'. Matthew Black and James C. VanderKam, The Book of Enoch, or I Enoch with Commentary and Textual Notes; with an Appendix on the Astronomical Chapters (72-82) by Otto Neugebauer (SVTP 7; Leiden: Brill, 1985): 290 suggest that the 'house' may also be an allusion to the royal house(hold) of David, following 2 Sam. 7:16. That the 'house' is burned with fire in 93:8 makes a reference to a physical structure more likely. Their suggestion eases the tension arising from the destruction in the sixth week of the permanent 'house' built in the fifth. But the endurance of the temple was always conditional upon the obedience of the people (1 Kings 9:7; 2 Chron. 7:20; Jer. 7:1-15), and the juxtaposition of these two events has considerable rhetorical impact.

9 Nickelsburg, 1 Enoch 1, 446, 449.

10 Nickelsburg, 1 Enoch 1, 446-47; Christoph Berner, Jahre, Jahrwochen und Jubiläen: heptadische Geschichtskonzeptionen in Antiken Judentum (BZAW 363; Berlin/New York: Walter de Gruyter, 2006): 141. The words היכל ('temple'), מלכות 
The wilderness tabernacle appears briefly in the fourth week, ${ }^{11}$ but the Second Temple is completely overlooked. There is no return from exile, no rebuilding of Jerusalem and no Second Temple. Just a perverse generation with perverse deeds. The Second Temple looks like an aberration. Nickelsburg describes its absence as 'a wholesale condemnation of the return, the restoration, the rebuilding of the temple, and the events of the Persian and Hellenistic periods'. ${ }^{12}$ This is an argument from silence to be sure, ${ }^{13}$ but given the passing reference to the tabernacle in week four, the central place of Solomon's temple in weeks five and six, and the superlatives employed in the description of the eschatological temple in week eight, the silence is surely significant. ${ }^{14}$ The Second Temple standing in Jerusalem looks like the elephant in the room.

This text, apparently composed while the Second Temple was functioning, completely overlooks it. It venerates Solomon's temple in the past and anticipates the establishment of an eschatological temple in the future. This is the fulfilment of God's purposes prefigured by Solomon's temple.

('kingdom'), and כבוד ('glory'), as well as the notion of endurance, appear in the description of the eschatological temple complementing similar ideas in the description of Solomon's temple.

11 The Ethiopic word is 'atsad (Nickelsburg, 1 Enoch 1, 446). Wolf Leslau, Comparative Dictionary of Ge 'ez (Classical Ethiopic): Ge 'ez-English / English-Ge'ez with an Index of Semitic Roots (Wiesbaden: Harrassowitz, 1991): 74 defines this word as a 'circumscribed area', including a 'tent'. R. H. Charles, 'Book of Enoch' in APOT, vol. 2, ed. R. H. Charles (Oxford: Clarendon, 1913): 163-277: esp. 263 and Olson, Enoch, 220 render the word with 'enclosure,' suggesting a reference to Palestine. E. Isaac, '1 (Ethiopic Apocalypse of) Enoch: A New Translation and Introduction' in OTP, vol. 1, ed. J. H. Charlesworth (New York, NY: Doubleday, 1983): 6-89: esp. 74 translates 'a law shall be made with a fence' and opines that the fence could be around the Torah, as in $m$. Abot 1.1. A sixth- or seventh-century AD Coptic fragment of ApW found in Egypt in 1937 contains the word skenee ('tent') at this point. See S. Donadoni, 'Un frammento della versione copta del "libro di Enoch"', AcOr 25 (1960): 197-202 and Milik, Books of Enoch, 81-82. Those who read a reference to the tabernacle include August Dillmann, Das Buch Henoch (Leipzig: Vogel, 1853): 295; Black and VanderKam, 1 Enoch, 290; Nickelsburg, 1 Enoch 1, 446; Stuckenbruck, 1 Enoch 91$108,107-108$.

12 Nickelsburg, 1 Enoch 1, 447.

13 There is no specific polemic against temple, cult and priesthood, as García Martínez, Qumran and Apocalyptic, 89; Martha Himmelfarb, 'Temple and Priests in the Book of the Watchers, the Animal Apocalypse and the Apocalypse of Weeks' in The Early Enoch Literature, ed. Gabriele Boccaccini and John J. Collins (Leiden/Boston: Brill, 2007): 210-35, esp. 233-34; Stuckenbruck, 1 Enoch 91-108, 137-38 point out.

14 Nickelsburg, 1 Enoch 1, 447-49. 


\section{Hebrews}

Hebrews explicitly mentions neither Solomon's Temple nor the Second Temple, and several scholars have argued that the author has no interest in the Second Temple, and its rituals, ${ }^{15}$ instead basing his arguments on the wilderness tabernacle, although, to be sure, the tabernacle is only explicit in a few verses in Hebrews 8-9.16 Both Walker and Motyer have argued that the temple is ignored for rhetorical reasons, ${ }^{17}$ and Walker argues that Hebrews 13:9-14, in particular, indicates that those addressed in Hebrews were attracted to Jewish festivals centred on the temple, that the references to 'the camp' in those verses refer to Jerusalem, and that 'those who serve in the tent' (13:10) are the Jerusalem priests, with the 'tent' being a deliberately archaised reference to the temple. ${ }^{18}$

There is no need to repeat the arguments put forward by Walker and Motyer; ${ }^{19}$ rather, in what follows I will briefly rehearse the arguments from Heb. 10:1-4, 11-12 for composition while the temple was still standing, and for a critique of the sacrificial system. I will then survey several other texts in Hebrews that first-century readers are likely to have heard as referring to and critiquing the contemporary priesthood and temple. ${ }^{20}$

15 Harold W. Attridge, The Epistle to the Hebrews (Hermeneia; Minneapolis, MN: Fortress, 1989): 8; William L. Lane, Hebrews 1-8 (WBC 47A; Dallas, TX: Word, 1991): 1xiii; Paul Ellingworth, The Epistle to the Hebrews (NIGTC; Grand Rapids, MI: Eerdmans, 1993): 29-30, 401, 710; Craig R. Koester, Hebrews: A New Translation with Introduction and Commentary (AB 36; New York, NY: Doubleday, 2001): 49-53; Peter T. O'Brien, The Letter to the Hebrews (The Pillar New Testament Commentary; Grand Rapids, MI/Cambridge: Eerdmans, 2010): 14.

16 Heb. 8:5b; 9:1-10, 21, 23.

17 Motyer, 'Temple in Hebrews', 180-89; Walker, 'A Place for Hebrews', 239-41.

18 Walker, 'Jerusalem', 39-71; Walker, Holy City, 205-208.

19 Motyer, 'Temple in Hebrews', 182-89 examines Heb. 3:1-6; 4:14; 6:19-20; 7:13; $8: 1-6,11 ; 9: 1-14 ; 10: 11-14 ; 13: 13-14$, and finds that in each of these texts 'the Temple appears in disguise, lurking under the surface as an implicit referent within the wider argument'. Walker, 'Jerusalem', 39-71 concentrates on Heb. 13:9-14, which he elsewhere notes 'would mean nothing unless he [the author of Hebrews] was thinking about the Jerusalem Temple ... [a]ny other interpretation reduces the author's concerns to the level of vague abstractions' (Walker, Holy City, 206).

20 In what follows I sometimes argue from the use of the Greek present tense. I am aware of the complexity surrounding the interplay between aspect and time in Greek, and that it is over-simplification to equate the Greek present tense with present time. However, I am simply arguing that nothing in these texts excludes a reference to the Second Temple and its priesthood and rituals, and that contextual factors sometimes indicate that this priesthood is in view. See the critique of the uncritical use of Greek tenses to establish the date of Hebrews in Stanley E. Porter, 'The Date of Composition 


\section{Hebrews 10:1-4, 11-12}

Hebrews 10:1-4 is a single sentence concluding with the declaration that animal sacrifices cannot remove sins. Verse 2 claims that the same sacrifices which are continually offered year after year would have ceased being offered if they could make the worshippers perfect, and since they have not ceased, the people are still conscious of sin. I have deliberately paraphrased the sentence in this way, supplying the

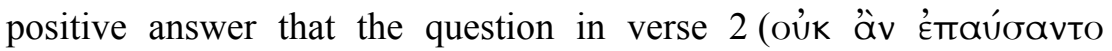
пробфєро́ $є \varepsilon \vee \alpha$, 'would they not have ceased being offered?') demands. Some scholars argue that the present tense verbs in this sentence have no bearing on the date of Hebrews, ${ }^{21}$ since there are other texts that refer to temple sacrifices in the present tense after it had been destroyed. ${ }^{22}$ But these writers were not discussing the end of the former cultus as was the author of Hebrews, and had the temple been destroyed when he wrote, he could have driven the point home by pointing to that event. ${ }^{23}$

The present tense in Greek indicates an action viewed by a speaker as it unfolds, usually in the present time. ${ }^{24}$ But since it is not always in the present time, lexical, contextual and grammatical factors as well as the features of the discourse must be considered. ${ }^{25}$ In the context of

of Hebrews and Use of the Present Tense Form' in Crossing the Boundaries: Essays in Biblical Interpretation in Honour of Michael D. Goulder, ed. Stanley E. Porter et al. (Leiden: Brill, 1994): 295-313.

21 Attridge, Hebrews, 8; Koester, Hebrews, 52-53; Pamela Michelle Eisenbaum, 'Locating Hebrews within the Literary Landscape of Christian Origins' in Hebrews: Contemporary Methods - New Insights, ed. Gabriella Gelardini (Biblical Interpretation Series 75; Leiden/Boston: Brill, 2005): 213-37, esp. 225.

22 Josephus Ant. 3.102-87, 224-57; Ag. Ap. 2.77, 193-98; 1 Clem. 40-41; m. Qid. 1.8.

23 Walker, 'Jerusalem', 58-59 (n. 37); Donald A. Hagner, Encountering the Book of Hebrews (Encountering Biblical Studies; Grand Rapids, MI: Baker, 2002): 25.

24 Stanley E. Porter, Idioms of the Greek New Testament (Sheffield: JSOT Press, 1994): 21; Daniel B. Wallace, Greek Grammar beyond the Basics: An Exegetical Syntax of the New Testament (Grand Rapids, MI: Zondervan, 1996): 514. Constantine R. Campbell, Verbal Aspect in the Indicative Mood, and Narrative: Soundings in the Greek New Testament (Studies in Biblical Greek 13; New York: Peter Lang, 2007): 35-37 thinks that the present tense has no bearing on time, but that is surely an overstatement. Philip Edgcumbe Hughes, A Commentary on the Epistle to the Hebrews (Grand Rapids, MI: Eerdmans, 1977): 30-32 lists all the places where the author of Hebrews uses the present tense with reference to the temple and argues that they all indicate that the temple was still standing, but he seems to overstate his case, see the critique in Porter, 'Date', 296-98.

25 Stanley E. Porter, Verbal Aspect in the Greek of the New Testament with Reference to Tense and Mood (Studies in Biblical Greek 1; New York: Peter Lang, 1993): 98102; Porter, 'Date', 304-305. 
Hebrews 10:1-4, the question about the cessation of sacrifice makes it almost certain that the temple was still in place with the sacrifices still being offered. ${ }^{26}$

The critique of the sacrificial system reappears in verses 11-12, which refer to every priest who stands, 'serving and offering the same

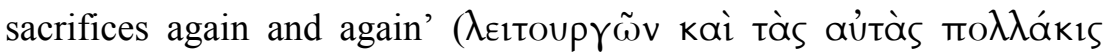

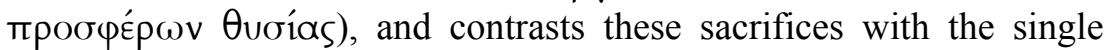
sacrifice of Christ.

The station of the priests is expressed with the perfect indicative of

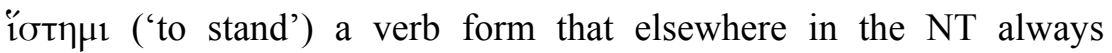
indicates present time. ${ }^{27}$ The text envisages these priests as standing and offering the same sacrifices, and contrasts them with the priest of

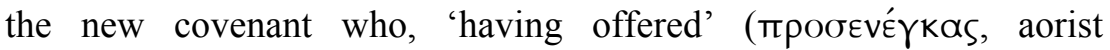

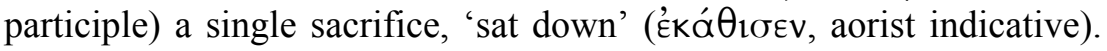
To be sure the argument is about the ineffectiveness of the Levitical cultus, but there is no indication in the text that the reference is to be restricted to former priests standing in the wilderness tabernacle. For that, one would expect a pluperfect. Indeed, Attridge's rendering 'the typical priest of old "has stood"' and Koester's 'every priest has stood' imply a pluperfect rather than a perfect and betray a preference for a date after AD 70 (although neither definitively discounts an earlier date).$^{28}$ If the recipients had heard a reference to the Second Temple and its priesthood in verses 1-4, they would also have heard it here. ${ }^{29}$

Hebrews 10:1-4, 11-12 imply that the temple was still standing and the temple cult still functional when Hebrews was written, and critique that cult as ineffective. I now turn to several earlier references to the

26 F. F. Bruce, The Epistle to the Hebrews (rev. edn; NICNT; Grand Rapids, MI: Eerdmans, 1990): 22; Walker, Holy City, 227-28; Motyer, 'Temple in Hebrews', 188; Robert P. Gordon, Hebrews (2nd edn; Readings: A New Biblical Commentary; Sheffield: Sheffield Academic Press, 2008): 33; O’Brien, Hebrews, 18-19.

27 Buist Fanning, Verbal Aspect in New Testament Greek (Oxford Theological Monographs; Oxford: Clarendon, 1990): 299 includes Heb. 10:11 as an example of the use of the perfect indicative of i $\sigma \tau \eta \mu 1$ to refer to the present. This verb form appears ten times in the NT (John 1:26; Acts 7:33; 26:6, 22; Rom. 11:20; 1 Cor. 7:37; 2 Tim. 2:19; Heb. 10:11; Jas 5:9; Rev. 3:20) and a present time reference is always clear from the context. See the discussion in Wallace, Grammar, 579-80.

28 Attridge, Hebrews, 279; Koester, Hebrews, 430, 434, 440. For a past time reference with the pluperfect of iotnuı see Matt. 13:2; Luke 23:35; John 1:35; 18:5; 20:11. See the discussions of the date of Hebrews in Attridge, Hebrews, 6-9, and Koester, Hebrews, 50-54.

29 Cf. Motyer, 'Temple in Hebrews', 188, '10:11 is the closest the author comes to a direct attack on the Temple.' 
priesthood and to cultic places in Hebrews that should be read with reference to the temple and priesthood rather than the tabernacle.

\section{Hebrews 7: The Contemporary Priesthood}

Hebrews 7 compares the Levitical priesthood with priesthood like that of Melchizedek, sometimes referring to the Levitical priesthood in the present tense in ways that would have been read by those addressed in Hebrews with reference to their contemporaries in the temple.

Hebrews 7:5 argues that that 'those from the descendents of Levi'

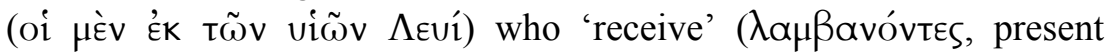
participle) the priesthood 'have' ('́Xovoiv, present indicative) a legal provision enabling them to collect a tenth from their contemporaries. The present tenses could refer to all who at any time have received the priesthood, including the priests of the Second Temple, to whom this regulation still applied. ${ }^{30}$

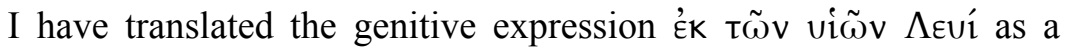
partitive genitive, although its precise force is debated. BDF, hesitatingly, suggests this reading, as do several other scholars, some of whom refer to contemporary practice. ${ }^{31}$ Ellingworth discounts any reference to the contemporary priesthood, when he writes,

not all the descendants of Levi were priests. This was certainly the case by the first century $\mathrm{AD}$, and the distinction between priests and levites may already be foreshadowed in Nu. 18:28; cf. Ne. 10:38. But the distinction is far from clear in the Pentateuch, the record of the period of Israel's history which was normative for the author of Hebrews. ${ }^{32}$

Ellingworth ultimately identifies the genitive as derivative ('those who, as members of Levi's family, take priestly office'), although it is unclear if he does so because he presupposes that the author is thinking

30 Lane, Hebrews 1-8, 168; Gareth Lee Cockerill, The Epistle to the Hebrews (NICNT; Grand Rapids, MI: Eerdmans, 2012): 309. For the legal provision see Num. 18:21-24, and for its application in the First Century see Josephus, Life, 80; Ant, 20.181, 206-207.

31 BDF 90, §164 (1); Hughes, Hebrews, 252; Bruce, Hebrews, 163; Attridge, Hebrews, 195; Koester, Hebrews, 344.

32 Ellingworth, Hebrews, 362. Cf. Attridge, Hebrews, 195, n. 121, who suggests a distinction between 'priests and non-priestly levites'. Bruce, Hebrews, 163 also notes that contemporary practice may have led to the author making such a distinction, but 'in general his description of the laws relating to the priesthood and sanctuary is based on the Pentateuch and not on contemporary custom'. 
of the regulations in the Torah rather than of his contemporaries in the temple. ${ }^{33}$ I question, however, the assumption that the pentateuchal period was normative for the author of Hebrews, and I question whether the implied readers of Hebrews would have drawn such a distinction. If they were attracted to the temple and its ritual as Walker and Motyer have argued, the contemporary priesthood would have come to mind, especially since the regulations about tithing were still in force.

Hebrews 7:20, 23 both contain periphrastic perfects with the present

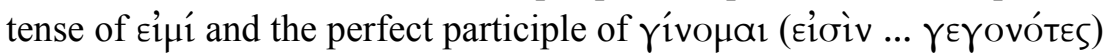
to refer to 'those who have become priests'. This construction has the same semantic force as the perfect indicative, ${ }^{34}$ but as recent research into the perfect tense has shown, the 'present results of a past action' understanding is inadequate. ${ }^{35}$ Thus it is tenuous to argue that these texts refer to those still holding the priesthood. ${ }^{36}$ But they cannot for that reason be excluded. Hebrews 7:20 refers to those who have become priests without an oath, and 7:23 to the numerous Levitical priests; numerous because they are prevented by death from continuing in office. ${ }^{37}$ In both cases people attracted to the existing priesthood would think of their contemporaries in the Jerusalem temple.

The NRSV and the ESV of Hebrews 7:23 obscure any reference to contemporary priests, both reading 'the former priests were many in number because they were prevented by death from continuing in office'. The Greek text has no word for 'former' and 'were prevented

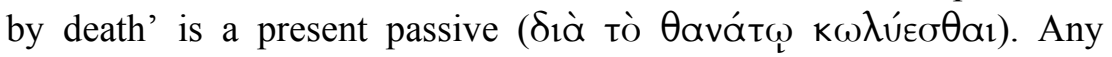

33 Ellingworth, Hebrews, 362. Ellingworth follows B. F. Westcott, The Epistle to the Hebrews (2nd edn; Grand Rapids, MI: Eerdmans, 1892): 175-76. See also Cockerill, Hebrews, 308 (n. 56).

34 Porter, Verbal Aspect, 251-59; Kenneth L. McKay, A New Syntax of the Verb in New Testament Greek (Studies in Biblical Greek; New York: Peter Lang, 1994): 9.

35 Porter, Idioms, 40; Campbell, Verbal Aspect in the Indicative Mood, 184-210; Constantine R. Campbell, Verbal Aspect in Non-Indicative Verbs: Further Soundings in the Greek New Testament (Studies in Biblical Greek 15; New York: Peter Lang, 2008): 36. In 'Breaking Perfect Rules: The Traditional Understanding of the Greek Perfect' in Discourse Studies \& Biblical Interpretation: A Festschrift in Honor of Stephen H. Levinsohn, ed. Stephen E. Runge (Bellingham, WA: Logos Bible Software, 2011): 139-55, Campbell argues that this understanding should be abandoned.

36 Ellingworth, Hebrews, 389-90 thinks that the periphrastic perfect implies that 'the old priesthood is still in existence'.

37 O'Brien, Hebrews, 272 notes that the entire succession of priests from Aaron to the fall of the temple can be encompassed in this text. 
priests in any era are being described, and there is nothing to restrict the reference to 'former' priests. ${ }^{38}$

\section{Hebrews 8:3-5: The Second Temple}

Walker has argued that the reference to those who serve the 'tent' in Hebrews 13:10 is an archaised reference to the temple. 'Tent' language first surfaces in Hebrews 8, and is also present in 9:1-21. It is clear that at times it refers to the wilderness tabernacle, especially in 9:1-7, but elsewhere there are indications that the Jerusalem temple is in view. I

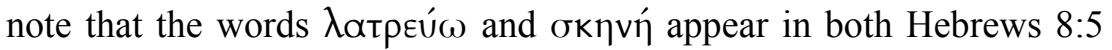
and 13:10, and if 13:10 is an archaised reference to the temple as 'the tent' as Walker maintains, then these intertextual echoes would send the reader back from $13: 10$ to $8: 5$ to see there too a reference to the temple. ${ }^{39}$

Hebrews 8:3-4 claims that every high priest is appointed to offer gifts and sacrifices. That the high priests in the Jerusalem temple are in view becomes clear in verse 4: Jesus would not be a priest 'if he was on

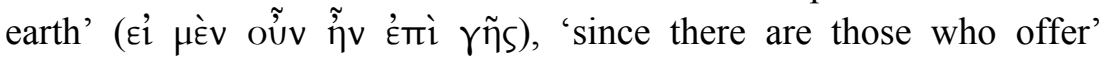

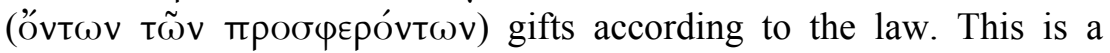
'contrary to fact' condition, a construction that normally uses an imperfect to refer to the present time from the author's perspective. ${ }^{40}$ Sometimes the imperfect refers to past time, ${ }^{41}$ however, in this context Christ is understood to be enthroned at the right hand of God now, ${ }^{42}$ and not now on earth. And if verse 4 were to be translated with a past time reference (cf. Lane- 'if he had been on earth') it would raise the

38 Porter, 'Date', 307 claims that it is clear that the priesthood in Jerusalem at the time of writing is not in view, although he does not say why. Perhaps he is thinking of those who had died. But if the temple was still standing and the cultus still functional, there is no reason to exclude the descendants of those who had died in the past.

39 Walker, 'Jerusalem', 60 refers to the author's 'consistent (and otherwise puzzling)

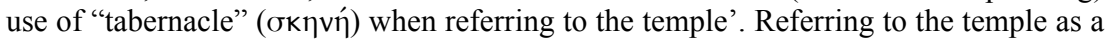
'tent' is not without precedent, e.g. Ps. 27 (LXX 26):4-5 refer to the temple with

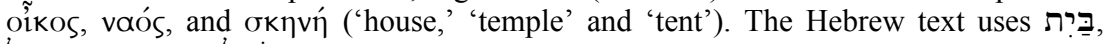

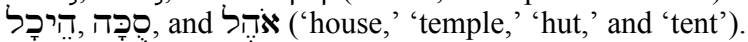

40 Wallace, Grammar, 695 .

41 See perhaps John 5:46; Heb. 8:7. Ellingworth, Hebrews, 405 suggests (following BDF 360 ) that the imperfect is 'temporally ambiguous'. Porter, Idioms, 260-61 points out that the construction need not have 'any temporal relation to the referential world'. 42 Luke Timothy Johnson, Hebrews: A Commentary (NTL; Louisville, KY/London: Westminster John Knox Press, 2006): 200. Cf. Koester, Hebrews, 377, 'if he were on earth (but he is not), he would not be a priest (although in fact he is a priest)'. 
question of whether Christ had ever been on earth. ${ }^{43}$ Thus, a present time reference best suits the context, with the implication that the rest of the verse also refers to the present time - these priests who offer the gifts according to the law are officiating in the temple now. ${ }^{44}$ These are

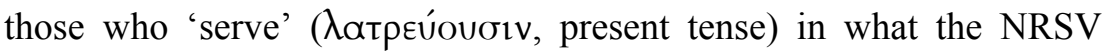
refers to as 'a sanctuary that is a sketch and shadow of the heavenly one'. This expression is normally understood to denigrate the tabernacle as a (mere, inferior) shadowy copy of the heavenly temple. ${ }^{45}$ I will return to this later.

\section{Hebrews 9:1-10: Tabernacle and Temple}

The detailed description in Hebrews 9:1-5 clearly refers to the tabernacle. It begins with imperfect and aorist tenses referring to the

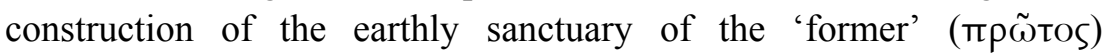
covenant. The text also describes the architecture of this sanctuary with

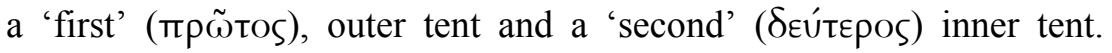
Present tense verbs in verses 6-7 describe the activities of the priests conducting their daily ritual in the first tent and their annual ritual in the second. These are probably gnomic presents referring to cultic

43 Ellingworth, Hebrews, 405. See Lane, Hebrews 1-8, 199 and NEB.

44 Gordon, Hebrews, 31-32. Attridge, Hebrews, 219; Ellingworth, Hebrews, 405 and

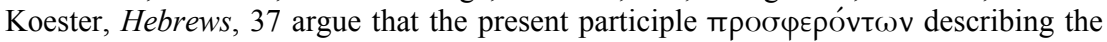
ministry of these priests says nothing about whether the priests were still functioning. This is technically correct, but is not the only consideration. The text discusses the present situation of Christ, and compares him with the service of the Levitical priests. Charles A. Gieschen, 'The Different Functions of a Similar Melchizedek Tradition in 2 Enoch and the Epistle to the Hebrews' in Early Christian Interpretation of the Scriptures of Israel: Investigations and Proposals, ed. Craig A. Evans and J. A. Sanders (JSNTSup 148; Sheffield: Sheffield Academic Press, 1997): 364-79, esp. 37374 lists Heb. 8:4 along with 9:6-10; 10:1-4 and 13:10 as implying 'contemporary sacrificial cult activity'. In his popular commentary, N. T. Wright, Hebrews for Everyone (London: SPCK, 2003): 81-85 discusses the temple rather than the tabernacle in connection with Heb. 8:1-5, and Lois K. Fuller Dow, Images of Zion: Biblical Antecedents for the New Jerusalem (New Testament Monographs 26; Sheffield: Sheffield Phoenix, 2010): 172-73 suggests that Heb. 8:5 implies that the Jerusalem temple is 'just a shadow of the real temple'.

45 Attridge, Hebrews, 219, and many others, see e.g. James A. Moffatt, A Critical and Exegetical Commentary on the Epistle to the Hebrews (Edinburgh: T\&T Clark, 1924): 105; Johnson, Hebrews, 202; O’Brien, Hebrews, 290. 
activities carried on in the tabernacle once the arrangements described in verses $1-5$ were in place. ${ }^{46}$

Verses 8-10 are more difficult. In verse 9, the first tent (the

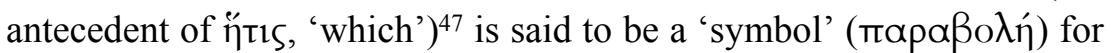
the present time, by which the Holy Spirit indicates that 'the way into the sanctuary is not yet revealed, while the first tent still has status'

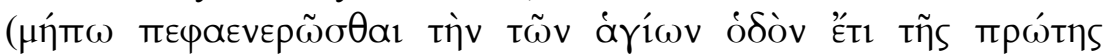

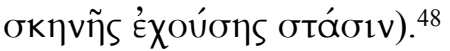

In Hebrews 9:2-3 the numbers 'first' and 'second' refer to the outer and inner tents respectively, and a reader encountering verse 8 for the first time would infer that the existence of the first (outer) tent was a figurative explanation that the way into 'the holy of holies' (in the tabernacle, tơ ớrı) had not yet been disclosed. But an alert reader would notice that the only previous occurrence of tò ór neuter plural) was in 8:2 where it referred to the heavenly temple. ${ }^{49}$

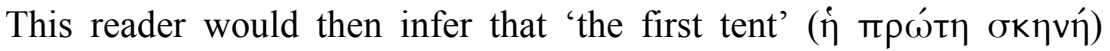
might also refer to the entire wilderness tabernacle, or perhaps the temple as in 8:5. ${ }^{50}$ Hebrews 9 uses $\pi \rho \tilde{\omega} t o s$ and $\delta \varepsilon u ́ t \varepsilon p o s$ both

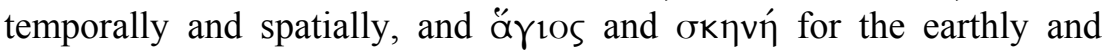
heavenly sanctuaries, both as a whole and also for their various parts.

\footnotetext{
46 Bruce, Hebrews, 21 and Walker, 'Jerusalem', 58 seem to favour the view that the author writes 'as if the ritual were still being enacted'.

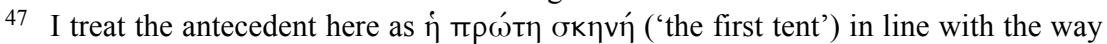
the relative pronoun óotıs consistently refers to a preceding substantive in Hebrews $(2: 3 ; 8: 5,6 ; 9: 2,8 \cdot 10: 8,11,35 ; 12: 5 ; 13: 7)$. See Norman H. Young, 'The Gospel According to Heb. 9', NTS 27 (1981): 198-210, esp. 201; Attridge, Hebrews, 241; William L. Lane, Hebrews 9-13 (WBC 47B; Dallas, TX: Word, 1991): 223-24; O'Brien, Hebrews, 313-14 (n. 51); Cockerill, Hebrews, 383 (n. 54). The other option is to read the antecedent of the pronoun as the entire state of affairs described in vv. 7-8, a reading adopted by O. Michel, Der Brief an die Hebräer (12. Auflage; Göttingen: Vandenhoeck \& Ruprecht, 1966): 22; Bruce, Hebrews, 209; Johnson, Hebrews, 25; James W. Thompson, Hebrews (Paideia Commentaries on the New Testament; Grand Rapids, MI: Baker Academic, 2008): 184.

48 For the reading 'has status' see Attridge, Hebrews, 240 (n. 127); Walker, Holy City, 209; Kenneth L. Schenck, Cosmology and Eschatology in Hebrews: The Settings of the Sacrifice (SNTSMS 143; Cambridge: Cambridge University Press, 2007): 150, 153.

49 Koester, Hebrews, 396-97; Lane, Hebrews 9-13, 216 (note r; Lane translates with 'real' sanctuary, in an allusion to 8:2).

50 Cockerill, Hebrews, 382 discounts this reading since the author 'could hardly call an "earthly sanctuary" the "First Tent" since it did not precede the eternal heavenly sanctuary of which it was a copy'. I will argue below that according to Heb. 8:5 the temple is a symbolic foreshadowing of the eschatological temple rather than a copy of the 'eternal heavenly sanctuary'.
} 
Thus, there is a double entendre with reference to both outer tent and entire sanctuary, and the earthly and heavenly temples. ${ }^{51}$

When read from the perspective of the design of earthly sanctuaries, the way into the holy of holies is not 'visible' ( avepó $\omega$ ) while the outer tent/court surrounds it. When read from the perspective of the distinction between the earthly and the heavenly sanctuaries, while the earthly sanctuary has status, the way into the presence of God is not

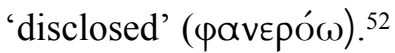

The reference to the first tent having status opens the door to reading the text in connection with the temple, ${ }^{53}$ especially when combined with the temporal expressions in verses 9-10. The first tent (the temple) is a symbol pointing 'to the present time' (Eis tòv kaipòv

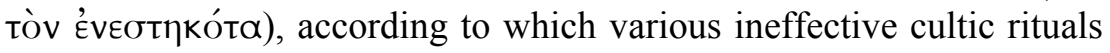
are imposed 'until the time of reformation' ( $\mu$ '́xрl kaıрoũ $\delta 10 \rho \theta \omega \sigma \varepsilon \omega \varsigma)$. These ineffective cultic rituals are the gifts and sacrifices which cannot perfect the conscience of the worshipper. These have already appeared in 8:3-4 in connection with the temple ritual. Here they are critiqued as inadequate. The text anticipates 10:1-4, 11 which refer to inability of the temple sacrificial system to achieve forgiveness.

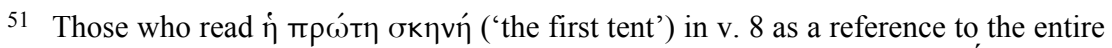
wilderness tabernacle include Moffatt, Hebrews, 118; Ceslas Spicq, L'Épître aux Hébreux (2 vols.; 3rd edn; Paris: Gabalda, 1952): 2: 253-54; Bruce, Hebrews, 208-209; Ellingworth, Hebrews, 438. Those who read it as referring to the outer tent of the wilderness tabernacle as in vv. 2, 6, 8 include Young, 'Gospel', 200-201; Koester, Hebrews, 396-97; Attridge, Hebrews, 240; Lane, Hebrews 9-13, 223; Schenck, Cosmology and Eschatology, 96-99, 149-55; O’Brien, Hebrews, 313; Cockerill, Hebrews, 381-82. These argue that to see it in any other way involves too subtle a change in meaning from the definition in v. 2 and the same expression in v. 6, with both vv. 6 and 9 part of the same periodic sentence (vv. 6-10). I am arguing that it is not a matter of either/or, but of both/and. For a double entendre in these verses see Steve Stanley, 'Hebrews 6:9-10: The "Parable" of the Tabernacle', NovT 37 (1995): 385-99, esp. 395-96; Johnson, Hebrews, 224.

52 The double entendre extends to the nuances in the verb pavepó $\omega$.

53 Schenck, Cosmology and Eschatology, 150-53 suggests that this may be an oblique reference to the readers' tendency to give the former age and covenant more status than was warranted. This also includes the temple. 


\section{Hebrews 8:5 'A Sketch and Shadow of the Heavenly One’ (NRSV)}

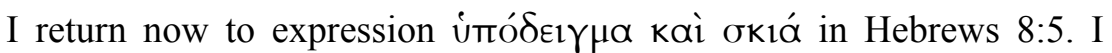
suggested above that in the ApW similarities in the descriptions of Solomon's temple and the eschatological temple indicated that the former anticipated the latter. I suggest that the same phenomenon is present here with reference to the Second Temple.

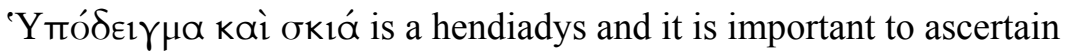
the contribution of each word to the single idea expressed. I begin with úmó $\delta \varepsilon 1 \gamma \mu \alpha$, normally read as 'copy'-that is, the copy of the heavenly sanctuary that Moses made (Exod. 25:9, 40). If we were restricted to the second edition of Bauer's lexicon, along with most other NT Greek lexicons from the Nineteenth and Twentieth Centuries, we could be forgiven for adopting this reading. ${ }^{54}$ But there are better tools than these. According to LSJ the word has the following senses: 'sign, token, indication ... illustration, picture showing how something is to be done ... pattern ... example ... instance or specimen'. ${ }^{55}$ LSJ nowhere suggests 'copy' as an appropriate rendering. The same applies to BDAG, which offers two definitions: 'example model, pattern' and 'an indication of someth[ing] that appears at a subsequent time, outline, sketch, symbol'. ${ }^{56}$

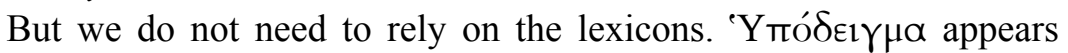
five times in the LXX. In four of these it has the sense of a moral example to be avoided or imitated, ${ }^{57}$ while in the fifth (Ezek. 42:15), it

\footnotetext{
54 Edward Robinson, A Greek and English Lexicon of the New Testament (New and improved edn revised by Alexander Negris and John Duncan; Edinburgh: T\&T Clark, 1876): 812; J. H. Thayer, A Greek-English Lexicon of the New Testament, being Grimm's Wilke's Clavis Novi Testamenti, Translated, Revised and Enlarged (4th edn; Edinburgh: T\&T Clark, 1898): 642-43; James Hope Moulton and G. Milligan, The Vocabulary of the Greek Testament: Illustrated from the Papyri and Other NonLiterary Sources (London: Hodder and Stoughton, 1930): 657; Heinrich Schlier,

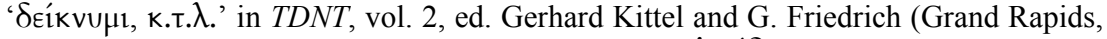
MI: Eerdmans, 1964): 25-33: esp. 33; R. P. Martin, 'únó $\delta \varepsilon 1 \gamma \mu \alpha$ ' in NIDNTT, vol. 2, ed. Colin Brown (Grand Rapids, MI: Zondervan, 1976): 290-91; EDNT 3: 402; TLNT 403-5; BADG 844.

55 LSJ 1878.

56 BDAG 1037.

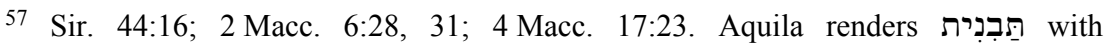
úró $\delta \varepsilon 1 \gamma \mu \alpha$ in Deut. 4:17 and Ezek. 8:10, where it appears to have the sense of 'image' or 'representation' (Frederick Field, Origenis Hexaplorum Quae Supersunt, Sive Veterum Interpretum Graecorum in Totum Vetus Testamentum Fragmenta (5 vols.; Oxford: Clarendon, 1870): 1: 279; 2: 788. In Deut. 4:17 LXX reads ó
} 
has the sense of 'pattern' or 'outline'. ${ }^{58}$ The statistics in the NT are similar. 'Y $Y o ́ \delta \varepsilon \imath \gamma \mu \alpha$ has the sense of a moral example to be followed or avoided four times (including one instance in Hebrews), ${ }^{59}$ leaving two other instances (Heb. 8:5; 9:23). Numerous scholars propose that it means 'copy' here, calling on Philo for help. But Philo is not much

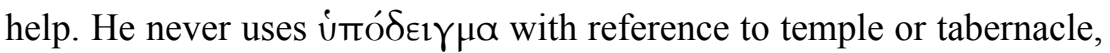
and when he uses the near synonym $\pi \alpha \rho \alpha \dot{\delta} \delta \varepsilon \gamma \mu \alpha$, it refers not to what Moses made, but to what Moses saw and used as a pattern to construct the tabernacle. ${ }^{60}$ In Philo, $\pi \alpha \rho \alpha ́ \delta \varepsilon \mathfrak{\gamma} \mu \alpha$ does not denigrate the tabernacle; rather it gives it a stamp of divine approval and great dignity, being modelled after a heavenly 'pattern' ( $\pi \alpha \rho \alpha ́ \delta \varepsilon 1 \gamma \mu \alpha){ }_{.}{ }^{61}$

The editors of BDAG refer to an essay by Lincoln Hurst, where, as well as in his later monograph, Hurst points out ' $[\mathrm{t}]$ here is no instance in known Greek literature where úmó $\delta \varepsilon \curlyvee \mu \alpha$ can be demonstrated to mean 'copy' ${ }^{62}$ Furthermore, he argues that it actually has the opposite sense, that is, 'a basis for something which comes later'. ${ }^{63}$ Indeed, BDAG notes that Attic writers rejected úmó $\delta \varepsilon \uparrow \mu \mu$ in favour of its

and Ezek. 8:10 LXX reads ónoíwors. However, Aquila must be treated with caution, since, as Frederick Field's Prolegomena to Origenis Hexaplorum Quae Supersunt, Sive Veterum Interpretum Graecorum in Totum Vetus Testamentum Fragmenta (CahRB; Paris: J. Gabalda et Cie Éditeurs, 2005): 46 points out, Aquila always attempts to express Hebrew words with the same Greek words, 'without any consideration of the meaning in context'. 'Yтó $\delta \varepsilon 1 \gamma \mu \alpha$ appears six times in Josephus, always as an example (J.W. 1.374, 507; 2.208, 397; 6.103, 106). In Eup. Frag. 2, 34:5 it refers to Solomon constructing the lamp stand for the temple, using as a 'model' (író $\delta \varepsilon \gamma \mu \alpha$ ) the lamp stand placed in the tabernacle by Moses.

58 Lincoln D. Hurst, The Epistle to the Hebrews: Its Background of Thought (SNTSMS 65; Cambridge: Cambridge University Press, 1990): 14.

59 John 13:15; Heb. 4:11; Jas 5:10; 2 Pet. 2:6.

60 Mos. 2.74. Пара́ $\delta \varepsilon 1 \gamma \mu \alpha$ appears twice in Exod. 25:9 with the sense 'pattern.'

61 Koester, Hebrews, 383.

62 Lincoln D. Hurst, 'How Platonic are Heb. viii.5 and ix.23f?' JTS 34 (1983): 156-

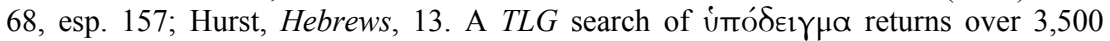
occurrences. Gregory E. Sterling, 'Ontology sersus Eschatology: Tensions ßetween Author and Community in Hebrews' in The Studia Philonica Annual: Studies in Hellenistic Judaism. Volume 13, ed. David T. Runia and Gregory E. Sterling (Providence, RI: BJS, 2001): 190-211, esp. 195 claims that in Middle Platonism únó $\delta \varepsilon 1 \gamma \mu \alpha$ occasionally has the sense of 'example [in the sense of] a copy of the idea that lay behind it', citing Philo Conf. 64 (Balaam an example of depravity); Her. 256 (instances of people being in a trance, which Johnson, Hebrews, 202 considers has the sense of 'example to be followed'); Somn. 2.3 (Jacob's vision of a ladder as an example of a kind of dream). In none of these cases is the 'example' a 'copy' in the sense that is argued for the earthly sanctuary as a copy of the heavenly in Hebrews. They are better described as 'instances of a topic being discussed', rather than 'copies of an idea'.

63 Hurst, Hebrews, 15. 


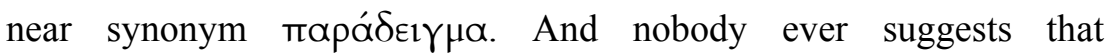
mapá $\delta \in 1 \gamma \mu \alpha$ has the sense of 'copy'. This word is always an 'example' or a 'pattern for imitation'. ${ }^{64}$

In Hebrews 8:5 the relationship is further described with the word oKı⿱㇒́ ('shadow'). For this word BDAG lists three senses: shade (from light and/or heat); the shadow cast by an object; and a "mere representation of someth[ing] real'. ${ }^{65}$ But there is another option, that is, 'foreshadowing' as BAGD (1979) suggests for Hebrews 10:1 and Colossians 2:17.66 In these texts the context suggests 'foreshadowing', with the word $\mu \varepsilon \lambda \lambda$ óvt $\omega v$, referring to what is 'about to happen', in close proximity. In Hebrews 8:5 úmó $\delta \varepsilon 1 \gamma \mu \alpha$, referring to the temple as an outline or symbol of something that will come later, gives to okı́ the same forward looking nuance. ${ }^{67}$ Thus I argue that the text presents

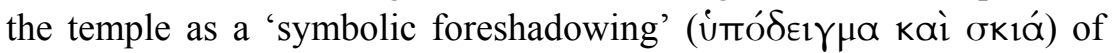
'the heavenly things' (тò émoupóvia).

The NRSV reads tà ÉTroupávia as a reference to the heavenly sanctuary (tò ória in Heb. 8:2). This would be reasonable if

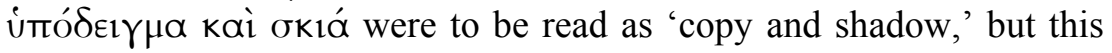
reading is suspect, and tà ó $ү 1 \alpha$ in Hebrews 8:2 is a long way from 8:5.

64 LSJ 1307-1308 defines $\pi \alpha \rho \alpha \delta \varepsilon^{\prime} \gamma \mu \alpha \tau \alpha$ as 'the divine exemplars after which earthly things are made'. There is no entry for mapá $\delta \varepsilon 1 \gamma \mu \alpha$ in BDAG, although it is mentioned in connection with $\pi \alpha p \alpha \delta \varepsilon 1 \gamma \mu \alpha t i \zeta \omega$ and glossed with 'model' (p. 761).

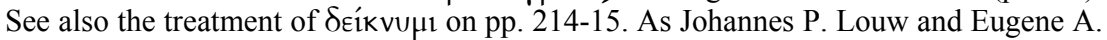
Nida, Greek-English Lexicon of the New Testament based on Semantic Domains (2 vols.; New York, NY: United Bible Societies, 1988): 339-40, 591 show, the semantic range of this word group nowhere extends to the sense of a 'copy'.

65 BDAG 929.

66 BAGD 755, s.v. oKıó, 2 has a separate sense of 'shadow, foreshadowing' under which Heb. 8:5 and 10:1 are listed, without specifying whether the sense in these verses is shadow or foreshadowing. BDAG 929-30 includes the sense 'foreshadowing' in the third option with Col. 2:17 as an example. See also Louw and Nida, Lexicon, 593, §58.65; Bruce, Hebrews, 184-85.

67 Hurst, Hebrews, 17 argues that the author 'deliberately coupled úmó $\delta \varepsilon 1 \gamma \mu \alpha$ with oKı⿱㇒́ in order to guarantee that the latter would have a forward nuance identical to its usage in 10:1'. Kiwoong Son, Zion Symbolism in Hebrews: Hebrews 12:18-24 as a Hermeneutical Key to the Epistle (Paternoster Biblical Monographs; Milton Keynes: Paternoster, 2005): 176-80 critiques Hurst's interpretation of úmó $\delta \varepsilon 1 \gamma \mu \alpha$, arguing that Hurst has adopted a dominant meaning of the word ('example' or 'pattern'), and not paid enough attention to the discourse situation and the context in Heb. 8, which shows that another less frequent meaning ('copy') is intended. Son rightly notes that the meanings of words can change over time and that words can have different meanings in different situations. However, he fails to recognise that the word only carries the sense of 'copy' in Aquila's literal translation of Deut. 4:17 and Ezek. 8:10, where the sense is suspect. Attridge, Hebrews, 219, n. 41 and Schenck, Cosmology and Eschatology, 118, n. 9 also appeal uncritically to Aquila for this sense of úmó $\delta \varepsilon 1 \gamma \mu \alpha$. 
'Heavenly things' is a better rendering. ${ }^{68}$ An examination of ÉTroupávios elsewhere in Hebrews clarifies the sense of this word. It appears six times, four as an attributive adjective ${ }^{69}$ and twice as a substantive. ${ }^{70}$ As an adjective, it has an eschatological nuance: the things described as heavenly all have a future orientation. As Cora Brady notes, "[t]here is a world to come and a heavenly country, a city to come and a heavenly Jerusalem, good things to come and heavenly things; those who have tasted the heavenly gift have also tasted the powers of the world to come' ${ }^{71}$ The same nuance is present in this text. The 'heavenly things' are contrasted with the earthly things that point to them. These are the eschatological realities that have come with the exaltation of Jesus to the right hand of God; God's dwelling with his people in the eschaton, now in place 'in these last days' ${ }^{72}$

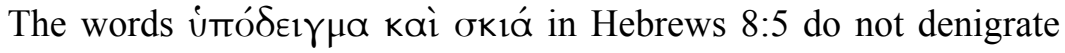
the tabernacle as a shadowy copy of an archetypal heavenly temple as is so often assumed. Indeed, if the priests in the temple are in view in $8: 4$, then 8:5 describes not the tabernacle but the temple, and the tabernacle appears in the second half of 8:5 simply as confirmation from the Torah of the relationship between earthly sanctuaries and the heavenly, eschatological sanctuary. God showed Moses the heavenly

68 Attridge, Hebrews, 216 translates Énoupavía with 'heavenly things', but also refers to the heavenly temple (p. 216) and heavenly tabernacle (p. 217); Bruce, Hebrews, 181 translates 'the heavenly reality', and later refers to the heavenly sanctuary (p. 184); Ellingworth, Hebrews, 406 refers to heavenly and earthly 'tabernacles' and 'realities'; Koester, Hebrews, 374 translates 'a heavenly [sanctuary]', and later states that it could refer to 'heavenly realities' but prefers 'heavenly sanctuary' as 'the counterpart to the earthly tent' (p. 378).

69 Heb. 3:1 ('heavenly calling'); 6:4 ('heavenly gift'); 11:16 ('heavenly homeland'); 12:22 ('heavenly Jerusalem').

70 Heb. 8:5; 9:23.

71 Cora Brady, 'The World to Come in the Epistle to the Hebrews', Worship 39 (1965): 329-39, esp. 332.

72 Westcott, Hebrews, 216-17 suggests that tò Émoupávia refers to "the ideas of the Divine Presence and the realities of heaven ... "the heavenly order", the scene of the spiritual life with the realities that belong to it'. Cf. also Chrysostom, Homily XIV.3 where the heavenly things of Heb. 8:5 are interpreted with a forward-looking reference to the church over against the temple: 'The Church is heavenly, and there is nothing else than Heaven' (tr. by Philip Schaff, The Nicene and Post-Nicene Fathers: Chrysostom: Homilies on the Gospel of John and the Epistle to the Hebrews [A Select Library of the Christian Church 14; Peabody, MA: Hendrickson, 1994]: 933), see PG

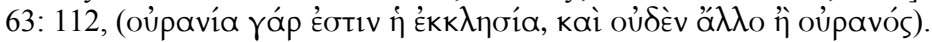


things to come and told him to build a tabernacle to prefigure that. ${ }^{73}$ This is a similar phenomenon as implied in ApW where Solomon's temple anticipates the eschatological temple. The difference is that in $\mathrm{ApW}$ the eschatological temple remains in the vague future of the eighth week; in Hebrews, it is in place with the exaltation of Christ to God's right hand 'in these last days' (1:2).

\section{Conclusion}

In ApW, Solomon's temple anticipates the eschatological temple, and the Second Temple is ignored. Hebrews, likewise, never explicitly refers to the Second Temple, but contains a sustained critique of temple, priesthood and sacrifice. However, while both texts critique the Second Temple, the critique is quite different. In ApW the entire enterprise of temple building is silently condemned because of a perverse generation with perverse deeds. In Hebrews while weakness is associated with the Second Temple in that it could not achieve the forgiveness it set out to achieve, there is no suggestion of perversity. Solomon's temple was revered in ApW, but it would be difficult to speak in these terms for the Second Temple in Hebrews, since it is subject to an ongoing critique. Nevertheless, it was clearly valid as a symbolic foreshadowing of what was to come. Now that heavenly things have come in Christ, the author needs to draw his readers away from involvement with ceremony centred on the temple. ${ }^{74}$ They are to direct their attention to Christ rather than to the symbol standing in Jerusalem.

Neither text explicitly refers to the Second Temple, but both leave open the possibility that the readers will draw the required inferences. For the readers of Hebrews to revert to the temple and its sacrifices now that the heavenly things are in place with the exaltation of Christ, is to be occupied with the anticipatory symbols rather than the reality to which they point. On the other hand, the readers of ApW are to view the perversity of their contemporaries associated with the rebuilt temple in the light of the glorious eschatological temple to come, just around

73 See the list of things shown to Moses in L.A.B. 19:12-13, including the eschatological temple. To be sure this is Nebo rather than Sinai, but it does reflect a tradition that God showed Moses eschatological realities.

74 Walker, 'Jerusalem', 40-50. 
the corner in the eighth week. Then everything will be put right and God will dwell with his people for many weeks without number forever (1 En. 91:17). 